\title{
Challenges and Needs of the Iranian Red Crescent Society in Response to the Great
} Flood of Iran in 2019

\author{
Ahmad Soltani $^{1,2} \mathbb{D}$, Farshid Alaedini ${ }^{6} \mathbb{D}$, Navvab Shamspour $^{3,6} \mathbb{D}, \underline{\text { Milad Ahmadi Marzaleh }^{1,2,4,5} \mathbb{D}}$
}

Date of submission: 7 Jun. $2020 \quad$ Date of acceptance: 19 Aug. 2020

\section{Original Article}

Abstract

INTRODUCTION: In the first half of April 2019, heavy rains in central and western parts of Iran resulted in great floods. The rains affected 24 provinces and caused extensive damage to urban and rural infrastructure. Since Iran, especially the northern, western, and southern provinces of Iran are prone to floods, the floods are expected to occur every year in many provinces. Therefore, the present study aimed to investigate the needs and problems of the Red Crescent Society in different provinces of Iran in response to the great flood of Iran in 2019.

METHODS: This cross-sectional study was performed in all provinces of Iran after the end of the flood response operations in April 2017. The required data were collected through a researchermade questionnaire and interviews with provincial operational managers. The designed questionnaire had different parts about the situation of the provinces in the face of floods, the most important problems faced during floods, and the most important needs for facing floods. Participants were also asked two questions about the information and equipment they should have had before the flood.

FINDINGS: Analysis of the answers revealed that 24 provinces ( $77.41 \%$ of the country) were affected by the floods. The most common problems were lack of equipment and low public awareness which were repeated by the subjects 24 and 17 times, respectively. Moreover, the need for specialized equipment and training courses were also the most important needs.

CONCLUSION: Based on the findings, the Iranian Red Crescent Society faced many problems and needs during the disaster relief process in the 2019 flood which indicated the lack of a comprehensive plan for flood management in Iran. Therefore, policymakers and disaster managers must develop practical and localized guidelines for relief according to the conditions of Iran in order to achieve the ultimate goal of disaster management which is to reduce deaths, injuries, and financial damages.

Keywords: Flood; Need; Preparedness; Problem; Response; Red Crescent Society.

How to cite this article: Soltani A, Alaedini F, Shamspour N, Ahmadi Marzaleh M. Challenges and

Needs of the Iranian Red Crescent Society in Response to the Great Flood of Iran in 2019. Sci J Rescue Relief 2020; 12(1): 77-83.

1-Research Center for Emergency and Disaster Resilience, Red Crescent Society of the Islamic Republic of Iran, Tehran, Iran

2-PhD, Applied Science Higher Education Institute, Red Crescent Society of the Islamic Republic of Iran, Tehran, Iran

3-PhD Student, Islamic Azad University, Tehran North Branch, Tehran, Iran

4-PhD, Health in Disasters and Emergencies, Student Research Committee, Department of Health in Disasters and Emergencies, Health Human

Resources Research Center, School of Management and Medical Informatics, Shiraz University of Medical Sciences, Fars, Iran

5-MPH of Health Policy, Health Policy Research Center, Institute of Health, Shiraz University of Medical Sciences, Fars, Iran

6-Research Center for Health Management in Mass Gathering, Red Crescent Society of the Islamic Republic of Iran, Tehran, Iran

Correspondence to: Milad Ahmadi Marzaleh, Email: miladahmadimarzaleh@yahoo.com 


\section{Introduction}

$\mathrm{S}$ evere climate change has increased the frequency and severity of natural disasters all around the world, which has had catastrophic effects on human life and the environment (1). One of the most common natural disasters in the world is the flood. Flood is defined as a large amount of water that flows rapidly, overflows, and covers an area of land that is normally dry. In other words, the flood is the relatively high rise of water in a river (2). This rising is relative and generally depends on the normal state of the water (3). Floods have damaged many parts of Iran, both in the form of flash and slow-rising floods. Flash flood refers to a flood caused by heavy rains in a short period that can result in severe damage (4).

The flood damage has been increasing every year in developed and developing countries (5). Flood is the most common natural disaster in all continents and the rate of flood-related deaths is the highest, compared to that of the other natural disasters (5). Floods have many consequences, such as increase in migration, increase of hunger, reduction of economic growth, increase in healthcare costs, and increase in mental illnesses (6). The health impacts of floods vary in different populations due to their different vulnerabilities and can sometimes be catastrophic (7).

The health impacts of floods can be divided into immediate, medium-term, and long-term categories. Immediate impacts include injury, drowning, and gastrointestinal disorders outbreak (8) while medium-term impacts consist of complex injuries, infected wounds, and infectious diseases. Moreover, long-term impacts include chronic illnesses, namely mental disorders and malnutrition (9). Based on the results of previous studies, floods negatively affect all aspects of the lives of the victims and communities in the short and long term and create many problems and needs for them (10). Various factors cause improper flood management, such as lack of a unitary command, presence of several disaster commanders, improper distribution of donated goods, lack of rescue equipment, inadequate awareness of the experts and rescuers about the principles of disaster management, lack of attention to the needs, lack of attention to the importance of time management, and lack of proper cooperation of the rescue organizations $(11,12)$.
Heavy rains started in central and western Iran on March 17, 2019. These rains affected 24 provinces; however, Golestan, Khuzestan, and Lorestan were more damaged than the other provinces with 85 deaths, 2193 cases of injuries, and almost 35 thousand billion Tomans of financial damage to the urban and rural infrastructure. There were many problems in the response and management of this flood, which slowed down the management process. The Iranian Red Crescent Society is a nongovernmental organization that played an important and influential role in the rescue and management of the recent floods of Iran. Floods are expected to occur in many provinces every year since Iran, especially the northern, western, and southern provinces, are prone to floods. In this regard, the present study aimed to investigate the needs and problems of the Red Crescent Society of different provinces in response to the great floods of Iran in 2019.

\section{Methods}

This cross-sectional study was performed on all the provinces of Iran after the end of flood response operations in April 2019. The required data were collected using a researcher-made questionnaire and the participants were the operational managers of the Red Crescent Society of all the provinces of the country. The questionnaire consisted of different parts about the situation of the provinces regarding floods with three answers, namely 1) without the risk of flood, 2) at the risk of the flood but not affected by it, and 3) affected with floods; the number of cities and villages affected by flood; problems of facing floods; the most important problem; needs for facing floods; and the most important needs. The participants were also asked two questions about the information and equipment they should have had before the flood.

Since the questions were open-ended, the collected data were analyzed and coded using the thematic analysis method. The thematic analysis consists of six steps, namely a) familiarization with the data b) assignment of primary codes, c) search for categories, d) review of the categories, e) definition and appellation of the categories, and f) preparation of a report (13). The collected data were entered into Excel software (version 2016) and analyzed. 


\section{Findings}

The questionnaires were completed in 31 provinces and the analysis of the answers revealed that Qom was the only province that was not at the risk of flood during the study period. In total, six provinces were at the risk of the flood but not affected by it, while 24 provinces $(77.41 \%$ of the country) were affected by the flood. The most common problems faced by the operational teams of the Red Crescent Society were the lack of equipment and the low awareness of the people which were repeated 24 and 17 times by the subjects, respectively. Moreover, the most important problem was the lack of equipment and low public awareness with six and four repetitions, respectively.

Operational managers required specialized equipment, such as inflatable boats, tractors, vehicles for driving through the flood, buoyancy equipment, personal protective equipment, and sump pumps. The need to train people about the preparation of first aid kits, storage of water and food, evacuation and going to shelters, and important health issues were among the most repeated needs.

Furthermore, it was also emphasized to train the operational teams about the rescue methods, the types of hazards, how to command and the disaster command system, how to coordinate within the organization, how to protect oneself and the people exposed to floods, and basic health issues. Problems and the most important ones of them, needs and the most important ones of them, required information and equipment before the disaster, and their frequencies are summarized in Table 1.

Table 1. Problems and the most important ones of them, needs and the most important ones of them, required information and equipment before the disaster, and their frequencies

\begin{tabular}{|c|c|c|c|c|c|}
\hline $\begin{array}{l}\text { Required equipment } \\
\text { before the disaster } \\
\text { (frequency) }\end{array}$ & $\begin{array}{c}\text { Required information } \\
\text { before the disaster } \\
\text { (frequency) }\end{array}$ & $\begin{array}{c}\text { The most } \\
\text { important needs } \\
\text { (frequency) }\end{array}$ & $\begin{array}{c}\text { Needs } \\
\text { (frequency) }\end{array}$ & $\begin{array}{c}\text { The most } \\
\text { important problem } \\
\text { (frequency) }\end{array}$ & $\begin{array}{l}\text { Problem } \\
\text { (frequency) }\end{array}$ \\
\hline $\begin{array}{l}\text { inflatable boats and } \\
\text { buoyancy equipment } \\
\text { (5) }\end{array}$ & High-risk areas (3) & Equipment (12) & $\begin{array}{l}\text { Rescue } \\
\text { equipment, } \\
\text { such as cars } \\
\text { (24) }\end{array}$ & $\begin{array}{l}\text { Insufficient } \\
\text { equipment (6) }\end{array}$ & $\begin{array}{c}\text { Insufficient } \\
\text { equipment (24) }\end{array}$ \\
\hline $\begin{array}{l}\text { Flood rescue } \\
\text { equipment (4) }\end{array}$ & $\begin{array}{l}\text { Coordination methods } \\
\text { (3) }\end{array}$ & Education (9) & $\begin{array}{l}\text { Education } \\
\text { (24) }\end{array}$ & $\begin{array}{l}\text { Low public } \\
\text { awareness (4) }\end{array}$ & $\begin{array}{c}\text { Low public } \\
\text { awareness (17) }\end{array}$ \\
\hline $\begin{array}{l}\text { Cars with shock } \\
\text { absorbers (4) }\end{array}$ & Education (2) & $\begin{array}{l}\text { Improvement of } \\
\text { coordination (3) }\end{array}$ & $\begin{array}{l}\text { Determination } \\
\text { of the use of } \\
\text { the lands and } \\
\text { roads (12) }\end{array}$ & $\begin{array}{c}\text { Inadequate } \\
\text { knowledge of } \\
\text { disaster managers } \\
\text { (3) }\end{array}$ & $\begin{array}{l}\text { Destruction of } \\
\text { the } \\
\text { infrastructures } \\
\text { (15) }\end{array}$ \\
\hline Tractor (3) & $\begin{array}{l}\text { Information } \\
\text { management (2) }\end{array}$ & $\begin{array}{l}\text { Development of } \\
\text { an operational } \\
\text { plan (2) }\end{array}$ & $\begin{array}{l}\text { Inter- } \\
\text { organization } \\
\text { coordination } \\
\text { (7) }\end{array}$ & $\begin{array}{l}\text { Destruction of the } \\
\text { infrastructures (3) }\end{array}$ & $\begin{array}{l}\text { Inadequate } \\
\text { knowledge of } \\
\text { disaster } \\
\text { managers (12) }\end{array}$ \\
\hline Sump pumps (3) & $\begin{array}{l}\text { Usage of inflatable } \\
\text { boat and tractor (1) }\end{array}$ & $\begin{array}{c}\text { Information } \\
\text { management (1) }\end{array}$ & $\begin{array}{l}\text { Development } \\
\text { of a plan (7) }\end{array}$ & $\begin{array}{l}\text { Lack of quick alert } \\
\text { system (2) }\end{array}$ & $\begin{array}{c}\text { Incomplete } \\
\text { access to } \\
\text { information (12) }\end{array}$ \\
\hline $\begin{array}{l}\text { Complete diving suits } \\
\text { and equipment (2) }\end{array}$ & $\begin{array}{l}\text { Preparedness of aid } \\
\text { organizations (1) }\end{array}$ & $\begin{array}{l}\text { Determination of } \\
\text { the use of the } \\
\text { lands (1) }\end{array}$ & $\begin{array}{c}\text { Unitary } \\
\text { command (6) }\end{array}$ & $\begin{array}{l}\text { Lack of a unitary } \\
\text { command (2) }\end{array}$ & $\begin{array}{l}\text { Alteration of the } \\
\text { usage of the bed } \\
\text { of important } \\
\text { water resources } \\
\text { (11) }\end{array}$ \\
\hline $\begin{array}{l}\text { Dredging machines } \\
\text { (1) }\end{array}$ & $\begin{array}{l}\text { Social media } \\
\text { management (1) }\end{array}$ & $\begin{array}{l}\text { Reconstruction of } \\
\text { the infrastructure } \\
\text { (1) }\end{array}$ & $\begin{array}{c}\text { Proper } \\
\text { distribution of } \\
\text { donations (5) }\end{array}$ & $\begin{array}{l}\text { Alteration of the } \\
\text { usage of the bed of } \\
\text { important water } \\
\text { resources }(2)\end{array}$ & $\begin{array}{l}\text { Expert human } \\
\text { resource }(9)\end{array}$ \\
\hline
\end{tabular}




\section{Table 1. Continued}

\begin{tabular}{|c|c|c|c|c|c|}
\hline \multirow[t]{8}{*}{$\begin{array}{l}\text { Preparation of food } \\
\text { packages (1) }\end{array}$} & Unitary command (1) & $\begin{array}{l}\text { Establishment of } \\
\text { camp and } \\
\text { emergency } \\
\text { accommodation } \\
\text { (1) }\end{array}$ & $\begin{array}{l}\text { Information } \\
\text { management } \\
\text { (5) }\end{array}$ & $\begin{array}{l}\text { Lack of operational } \\
\text { program (2) }\end{array}$ & $\begin{array}{l}\text { Lack of unitary } \\
\text { command ( } 8)\end{array}$ \\
\hline & $\begin{array}{l}\text { Complete familiarity } \\
\text { with the hazards (1) }\end{array}$ & $\begin{array}{l}\text { Navigation of the } \\
\text { flood (1) }\end{array}$ & $\begin{array}{l}\text { Establishment } \\
\text { of camp and } \\
\text { emergency } \\
\text { accommodation } \\
\text { (3) }\end{array}$ & $\begin{array}{l}\text { Lack of unitary } \\
\text { management (1) }\end{array}$ & $\begin{array}{c}\text { Poor } \\
\text { management of } \\
\text { donations (8) }\end{array}$ \\
\hline & Call for air relief (1) & & $\begin{array}{c}\text { Development } \\
\text { of a plan (2) }\end{array}$ & $\begin{array}{c}\text { Lack of } \\
\text { coordination (1) }\end{array}$ & $\begin{array}{l}\text { Inadequate } \\
\text { training of the } \\
\text { rescue workers } \\
\text { (7) }\end{array}$ \\
\hline & $\begin{array}{l}\text { Lack of habitation in } \\
\text { the watercourse (1) }\end{array}$ & & $\begin{array}{l}\text { Organization } \\
\text { (2) }\end{array}$ & & $\begin{array}{l}\text { Lack of a relief } \\
\text { plan (5) }\end{array}$ \\
\hline & $\begin{array}{l}\text { Employment of } \\
\text { experts (1) }\end{array}$ & & $\begin{array}{l}\text { A quick alert } \\
\text { system (2) }\end{array}$ & & $\begin{array}{l}\text { Low safety of } \\
\text { the area (3) }\end{array}$ \\
\hline & $\begin{array}{l}\text { Possession of rescue } \\
\text { equipment (1) }\end{array}$ & & $\begin{array}{c}\text { Execution of } \\
\text { maneuvers (2) }\end{array}$ & & $\begin{array}{c}\text { Lack of } \\
\text { coordination (3) }\end{array}$ \\
\hline & & & $\begin{array}{l}\text { Reconstruction } \\
\text { of the } \\
\text { infrastructure } \\
\text { (1) }\end{array}$ & & $\begin{array}{l}\text { Low } \\
\text { effectiveness of } \\
\text { the rescue work } \\
\text { (2) }\end{array}$ \\
\hline & & & & & $\begin{array}{c}\text { Crowdedness } \\
\text { (2) } \\
\text { Lack of } \\
\text { monitoring (2) }\end{array}$ \\
\hline
\end{tabular}

\section{Discussion and Conclusion}

The present study aimed to investigate the needs and problems of the Red Crescent Society in different provinces of Iran regarding the response to the great flood of Iran in 2019. From the perspective of the Red Crescent operational managers of the country, lack of equipment, and low public awareness were the most common and important problem and need, respectively. Lack of equipment disrupts the relief process; therefore, organizations must equip themselves before the occurrence of disasters.

Moreover, the low awareness of people leads to their low perception of the risk and consequently low preparedness and inappropriate response. Therefore, the public should be provided with training on first aid kits, water and food storage, evacuation and going to shelters, and important health issues through mass media and social media or in person, before and after the flood. Moreover, the rescuers should be trained on rescue methods, the types of hazards, how to command, disaster command system, how to coordinate within the organization, how to protect themselves and people during floods, and basic health issues.

The managers also acknowledged that the identification of high-risk areas and coordination methods has a positive effect on flood management. High-risk areas and cities should be identified by experts to make it possible to take person-centered and risk mitigation measures before the occurrence of floods. Coordination is a very complex aspect that requires intra- and extraorganizational functions and can be improved by holding training sessions. Furthermore, inflatable boats, tractors, vehicles for driving through the 
flood, buoyancy equipment, personal protective equipment, and sump pumps were also mentioned as the needed equipment by the rescuers.

Proper communication and information exchange lead to greater coordination in response to emergencies, such as floods, and enhances the trust between the personnel. Inter-organizational challenges can be solved by information exchange. Information exchange should be in line with the concepts and perceptions of disaster managers and commanders. Provision of training courses can improve the level of knowledge, awareness, and performance of the personnel of organizations $(14,15)$.

Information documentation can help the improvement of communication and achievement of a common language among the personnel of the involved organizations, especially the Red Crescent Society and other disaster management organizations $(16,17)$. Transparent communication increases trust between organizations and usage of a unitary command allows the information to be transferred more accurately among the members of the organizations. It should be noted that the liaison officer plays a key role in linking organizations and will exchange information if it is needed $(18,19)$.

Relief workers and volunteers should be trained in strategies to prepare themselves, build capacity, and improve their knowledge and skills (20). Moreover, some strategies must be considered to make the presence of aid workers successful and effective in the country. Digitalization and online management are among the most important plans that facilitate the prevention and management measures of relief workers.

Destruction of the infrastructure prevents timely relief for flood victims. Therefore, the Ministry of Roads and Urban Development should establish scientific standards for the construction of bridges, roads, and urban infrastructure to prevent damage to these infrastructures in case of floods and not to interrupt relief work. Organizational communication with the above-mentioned organization facilitates the notification of people who are at risk.

The training courses should continue for at least 6 months and afterward, the strengths and weaknesses of the operation should be examined and efforts should be made to improve the strengths and eliminate the weaknesses (21). First aid, search and rescue, recognition of the first warning, triage in disasters, logistics and communications, and organizational team are the most important topics of training for the rescuers
(22).

Governmental, non-governmental, and quasigovernmental organizations should provide information about the expected harms of the disasters for the local people and residents and train them for disaster prevention and response. In addition, people must develop a disaster prevention plan with the help of other residents to be able to save their own lives immediately during floods and other disasters (23).

Donations make the victims feel that they are not alone, however, the inappropriate distribution of these gifts leads to a waste of resources and in some cases a lack of trust between donors and victims of relief organizations. However, development plans can lead to better management of these gifts. Therefore, policymakers in the field of crisis and disaster management should consider special protocols and programs to manage the donations and only a single organization should take full responsibility for it (11).

In the 2013 Jakarta flood, there was coordination between organizations despite the fact that the differences in the command and language created barriers for emergency operations (24). Implementation of an accident command system can solve the problem of having a unitary command and help meet the challenges of intraorganizational cooperation (17).

Multi-agency Coordination Systems (MACS) is an inter-organizational system for disaster response and resource management. Different organizations are placed within this system which increases the effectiveness and efficiency of their activities in response to disasters (21). Effective disaster management requires coordination at the international, national, and local levels (25). If relief organizations work together in the early post-disaster stages, the problems will be reduced to a minimum. Organizations that routinely collaborate with other organizations to promote and encourage these activities to coordinate and collaborate better (21).

The increase in the rate of flood hazards in Iran has a considerable impact on the lives of people. Development of disaster management policies that focus on the pre-disaster phase plays a vital role in the reduction of consequences and problems. Needs assessment by experts before the occurrence of disasters can also help to have more appropriate responses. At the level of headquarters, intra- and extraorganizational coordination are very important 
issues that can accelerate the relief process and make flood command more cohesive. However, the ranks and forces under the headquarters should possess the required relief equipment and train the personnel, experts, and even the public to empower them in order to properly conduct relief measures.

Finally, the following suggestions can help reduce vulnerability and strengthen the needed responses: 1) assess the needs before the disaster and troubleshoot them, 2) assign specialized training for aid workers, 3) train and inform the public, 4) develop a process of intra- and extraorganizational coordination, 5) hold regular training courses at least twice in a year to improve the readiness of responsible organizations, especially the Red Crescent Society, 6) develop a plan for resilience against floods, 7) develop a comprehensive plan for the construction and maintenance of the critical infrastructure, 8 ) initiate an integrated information management system, and 9) expand person-centered management during floods.

There were many problems and needs in the relief work by the Iranian Red Crescent Society in the 2019 flood. This issue indicated the need for the development and implementation of a comprehensive plan for flood management in Iran. Therefore, policymakers and disaster managers must develop practical and localized relief guidelines in accordance with the conditions of each province to deal with seasonal and flash floods and achieve the ultimate goal of disaster management which is to reduce deaths, injuries, and financial damages.

\section{Acknowledgments}

The authors would like to thank the CEO of the Red Crescent Society of all the provinces of Iran who paved the way for the performance of this study. They would also like to express their gratitude to the experts of the Iranian Crescent Institute of Applied Sciences who contributed to the conduction of this study.

\section{Conflict of Interests}

The authors declare that there was no conflict of interest in this study.

\section{Footnotes}

Authors' Contribution: Ahmad Soltani, Farshid Alaedini, Navvab Shamspour, and Milad
Ahmadi Marzaleh were responsible for the study conception and design. Ahmad Soltani, Navvab Shamspour, and Farshid Alaedini performed data collection and prepared the first draft of the manuscript. Ahmad Soltani, Farshid Alaedini, Navvab Shamspour, and Milad Ahmadi Marzaleh performed the data analysis, made critical revisions to the paper for important intellectual content, and supervised the study.

Informed Consent: Informed consent was obtained from all the participants of the research.

Funding/Support: The authors received no specific funding for this research project.

Financial Disclosure: There were no financial conflicts of interest to disclose.

\section{References}

1. Chau VN, Holland J, Cassells S, Tuohy M. Using GIS to map impacts upon agriculture from extreme floods in Vietnam. Appl Geography 2013; 41: 65-74.

2. Paterson DL, Wright $H$, Harris PN. Health risks of flood disasters. Clin Infect Dis 2018; 67(9): 1450-4.

3. Aerts J, Botzen W, Clarke K, Cutter S, Hall JW, Merz B, et al. Integrating human behaviour dynamics into flood disaster risk assessment. Nature Clim Change 2018; 8(3): 193-9.

4. Cred Crunch Newsletter. Flash floods: sharing of field experience - Kerala. India: Centre for Research on the Epidemiology of Disasters; 2018.

5. Wannous C, Velasquez G. United Nations Office for disaster risk reduction (UNISDR)-UNISDR's contribution to science and technology for disaster risk reduction and the role of the international consortium on landslides (ICL). Workshop on world landslide forum. Berlin, Germany: Springer; 2017.

6. Khan KA, Zaman K, Shoukry AM, Sharkawy A, Gani S, Ahmad J, et al. Natural disasters and economic losses: controlling external migration, energy and environmental resources, water demand, and financial development for global prosperity. Environ Sci Pollut Res 2019; 26(14): 14287-99.

7. Mallett LH, Etzel RA. Flooding: what is the impact on pregnancy and child health? Disasters 2018; 42(3): 432-58.

8. Reacher M, McKenzie K, Lane C, Nichols T, Kedge I, Iversen A, et al. Health impacts of flooding in Lewes: a comparison of reported gastrointestinal and other illness and mental health in flooded and non-flooded households. Communicable Dis Public Health 2004; 7(1): 39-46.

9. Du W, FitzGerald GJ, Clark M, Hou XY. Health impacts of floods. Prehosp Disaster Med 2010; 25(3): 265-72.

10. Fernandez A, Black J, Jones M, Wilson L, 
Salvador-Carulla L, Astell-Burt T, et al. Flooding and mental health: a systematic mapping review. PloS One 2015; 10(4): e0119929.

11. Peyravi M, Peyvandi AA, Marzaleh MA. Donations in the great flood of Iran, 2019: strengths and challenges. Iran Red Crescent Med J 2019; 21(5): e92904.

12. Peyravi M, Peyvandi AA, Khodadadi A, Marzaleh MA. Flood in the south-west of Iran in 2019; causes, problems, actions and lesson learned. Bull Emerg Trauma 2019; 7(2): 199.

13. Braun V, Clarke V. Using thematic analysis in psychology. Qualit Res Psychol 2006; 3(2): 77-101.

14. McMaster R, Baber C. Multi-agency operations: cooperation during flooding. Appl Ergon 2012; 43(1): 38-47.

15. Salmon P, Stanton N, Jenkins D, Walker G. Coordination during multi-agency emergency response: issues and solutions. Disaster Prev Manag Int J 2011; 20(2): 140-58.

16. Pramanik R. Challenges in coordination: differences in perception of civil and military organizations by comparing international scientific literature and field experiences. J Risk Res 2015; 18(7): 989-1007.

17. Scotter JRV, Pawlowski SD, $\mathrm{Cu}$ TD. An examination of interdependencies among major barriers to coordination in disaster response. Int $\mathrm{J}$ Emerg Manag 2012; 8(4): 281-307.

18. Rietjens SJ, Verlaan K, Zaalberg TW, De Boer SJ. Inter-organisational communication in civil- military cooperation during complex emergencies: a case study in Afghanistan. Disasters 2009; 33(3): 412-35.

19. Thompson WC. Success in Kashmir: a positive trend in civil-military integration during humanitarian assistance operations. Disasters 2010; 34(1): 1-15.

20. McLennan B, Whittaker J, Handmer J. The changing landscape of disaster volunteering: opportunities, responses and gaps in Australia. Natural Hazards 2016; 84(3): 2031-48.

21. Araghizadeh H, Peyravi M, Sharififar S, Ahmadi Marzaleh M. Civil-military coordination in natural disasters: a qualitative study. Iran Red Crescent Med J 2020; 22(1): e98793.

22. Kamal A, Songwathana P, Sia WS. Knowledge and skills of emergency care during disaster for community health volunteers: a literature review. Nurse Med J Nurs 2012; 2(2):371-81.

23. Haraoka T, Ojima T, Murata C, Hayasaka S. Factors influencing collaborative activities between non-professional disaster volunteers and victims of earthquake disasters. PloS One 2012; 7(10): e47203.

24. Nugroho SP, Pandanwangi TS, Suprapto S. Civilmilitary cooperation in disaster management. J Pertahanan 2016; 2(2): 129-44.

25. Morris JC, Morris ED, Jones DM. Reaching for the philosopher's stone: contingent coordination and the military's response to Hurricane Katrina. Public Administ Rev 2007; 67: 94-106. 